\title{
Potent neutralizing antibodies from COVID-19 patients define multiple targets of vulnerability
}

\author{
Philip J. M. Brouwer'*, Tom G. Caniels'*, Karlijn van der Straten ${ }^{1,2 *}$, Jonne L. Snitselaar', Yoann Aldon', \\ Sandhya Bangaru ${ }^{3}$, Jonathan L. Torres ${ }^{3}$, Nisreen M. A. Okba ${ }^{4}$, Mathieu Claireaux ${ }^{1}$, Gius Kerster', \\ Arthur E. H. Bentlage ${ }^{5}$, Marlies M. van Haaren', Denise Guerra', Judith A. Burger', Edith E. Schermer', \\ Kirsten D. Verheul ${ }^{1}$, Niels van der Velde ${ }^{6}$, Alex van der Kooi ${ }^{6}$, Jelle van Schooten ${ }^{1}$, Mariëlle J. van Breemen', \\ Tom P. L. Bijl1, Kwinten Sliepen', Aafke Aartse ${ }^{1,7}$, Ronald Derking', nja Bontjer', Neeltje A. Kootstra ${ }^{8}$, \\ W. Joost Wiersinga ${ }^{2}$, Gestur Vidarsson ${ }^{5}$, Bart L. Haagmans ${ }^{4}$, Andrew B. Ward ${ }^{3}$, Godelieve J. de Bree ${ }^{2 *}$, \\ Rogier W.Sanders ${ }^{1,9 *}$, Marit J. van Gils ${ }^{1 \dagger}$ \\ 'Department of Medical Microbiology, Amsterdam UMC, University of Amsterdam, Amsterdam Infection and Immunity Institute, 1105AZ Amsterdam, Netherlands. \\ ${ }^{2}$ Department of Internal Medicine, Amsterdam UMC, University of Amsterdam, Amsterdam Infection and Immunity Institute, 1105 AZ Amsterdam, Netherlands. ${ }^{3}$ Department \\ of Integrative Structural and Computational Biology, The Scripps Research Institute, La Jolla, CA 92037. USA. ${ }^{\circ}$ Department of Viroscience, Erasmus Medical Center, \\ 3015GD Rotterdam, Netherlands. ${ }^{5}$ Sanquin Research, Department of Experimental Immunohematology, Amsterdam, Netherlands, and Landsteiner Laboratory, Amsterdam \\ UMC, University of Amsterdam, 1006AD Amsterdam, Netherlands. ${ }^{6}$ BIS Technologies BV, 7521PR Enschede, Netherlands. ${ }^{7}$ Department of Virology, Biomedical Primate \\ Research Centre, 2288GJ Rijswijk, Netherlands. ${ }^{8}$ Department of Experimental Immunology, Amsterdam UMC, University of Amsterdam, Amsterdam Infection and Immunity \\ Institute, 1105AZ Amsterdam, the Netherlands. ${ }^{9}$ Department of Microbiology and Immunology, Weill Medical College of Cornell University, New York, NY 10021, USA. \\ *These authors contributed equally to this work. \\ †Corresponding author. Email: m.j.vangils@amsterdamumc.nl (M.J.v.G.); r.w.sanders@amsterdamumc.nl (R.W.S.); g.j.debree@amsterdamumc.nl (G.J.d.B.)
}

The rapid spread of SARS-CoV-2 has a significant impact on global health, travel and economy. Therefore, preventative and therapeutic measures are urgently needed. Here, we isolated monoclonal antibodies from three convalescent COVID-19 patients using a SARS-CoV-2 stabilized prefusion spike protein. These antibodies had low levels of somatic hypermutation and showed a strong enrichment in VH1-69, VH3-30-3 and VH1-24 gene usage. A subset of the antibodies were able to potently inhibit authentic SARS-CoV-2 infection as low as $0.007 \mu \mathrm{g} / \mathrm{mL}$. Competition and electron microscopy studies illustrate that the SARSCoV-2 spike protein contains multiple distinct antigenic sites, including several receptor-binding domain (RBD) epitopes as well as non-RBD epitopes. In addition to providing guidance for vaccine design, the antibodies described here are promising candidates for COVID-19 treatment and prevention.

The rapid emergence of three novel pathogenic human coronaviruses in the past two decades has caused significant concerns. The latest, severe acute respiratory syndrome coronavirus 2 (SARS-CoV-2), is responsible for over three million infections and 230.000 deaths worldwide as of May 1 , 2020 (1). The coronavirus disease 2019 (COVID-19), caused by SARS-CoV-2, is characterized by mild flu-like symptoms in the majority of patients. However, severe cases can present with bilateral pneumonia which may rapidly deteriorate into acute respiratory distress syndrome (2). With high transmission rates and no proven curative treatment available, health care systems are under severe pressure and stringent public health measures are in place to prevent infection. Safe and effective treatment and prevention measures for COVID-19 are urgently needed.

During the outbreak of SARS-CoV and Middle Eastern respiratory syndrome coronavirus (MERS-CoV), plasma of recovered patients containing neutralizing antibodies (NAbs) was used as a safe and effective treatment option to decrease viral load and reduce mortality in severe cases $(3,4)$.
Recently, a small number of COVID-19 patients treated with convalescent plasma, showed clinical improvement and a decrease in viral load (5). An alternative treatment strategy would be to administer purified monoclonal antibodies (mAbs) with neutralizing capacity. mAbs can be thoroughly characterized in vitro and expressed in large quantities. In addition, due to the ability to control dosing and composition, mAb therapy improves the efficacy over convalescent plasma treatment and prevents the potential risks of antibody-dependent enhancement (ADE) from non- or poorly NAbs present in plasma which consists of a polyclonal mixture (6). Recent studies with patients infected with the Ebola virus highlight the superiority of $\mathrm{mAb}$ treatment over convalescent plasma treatment $(7,8)$. Moreover, mAb therapy has been proven safe and effective against influenza virus, rabies virus, and respiratory syncytial virus (RSV) (9-11).

The main target for NAbs on coronaviruses is the spike (S) protein, a homotrimeric glycoprotein that is anchored in the viral membrane. Recent studies have shown that the S protein of SARS-CoV-2 bears considerable structural homology 
to SARS-CoV, with the S protein consisting of two subdomains: the N-terminal S1 domain, which contains the N-terminal domain (NTD) and the receptor-binding domain (RBD) for the host cell receptor angiotensin converting enzyme-2 (ACE2), and the S2 domain, which contains the fusion peptide $(12,13)$. Similar to other viruses containing class-1 fusion proteins (e.g., HIV-1, RSV and Lassa virus), the S protein undergoes a conformational change and proteolytic cleavage upon host cell receptor binding from a prefusion to a postfusion state enabling merging of viral and target cell membranes $(14,15)$. When expressed as recombinant soluble proteins, class-1 fusion proteins generally have the propensity to switch to a postfusion state. However, most NAb epitopes are presented on the prefusion conformation (16-18). The recent successes of isolating potent NAbs against HIV-1 and RSV using stabilized prefusion glycoproteins reflect the importance of using the prefusion conformation for isolating and mapping mAbs against SARS-CoV-2 $(19,20)$.

Early efforts in obtaining NAbs focused on re-evaluating SARS-CoV-specific mAbs isolated after the 2003 outbreak, that might cross-neutralize SARS-CoV-2 (21, 22). Although two mAbs were described to cross-neutralize SARS-CoV-2, the majority of SARS-CoV NAbs did not bind SARS-CoV-2 S protein or neutralize SARS-CoV-2 virus (12, 21-23). More recently, the focus has shifted from cross-neutralizing SARSCoV NAbs to the isolation of novel SARS-CoV-2 NAbs from recovered COVID-19 patients (24-28). S protein fragments containing the RBD have yielded multiple NAbs that can neutralize SARS-CoV-2 by targeting different RBD-epitopes (2428). In light of the rapid emergence of escape mutants in the RBD of SARS-CoV and MERS, monoclonal NAbs targeting other epitopes than the RBD are a valuable component of any therapeutic antibody cocktail $(29,30)$. Indeed, therapeutic antibody cocktails with a variety of specificities have been used successfully against Ebola virus disease (7) and are being tested widely in clinical trials for HIV-1 (31). NAbs targeting non-RBD epitopes have been identified for SARS-CoV and MERS, supporting the rationale to sort mAbs using the entire ectodomain of the SARS-CoV-2 S protein (32). In addition, considering the high sequence identity between the S2 subdomain of SARS-CoV-2 and SARS-CoV, using the complete S protein ectodomain instead of only the RBD may allow the isolation of $\mathrm{mAbs}$ that cross-neutralize different $\beta$-coronaviruses (33). In an attempt to obtain mAbs that target both RBD and non-RBD epitopes, we set out to isolate mAbs using the complete prefusion S protein ectodomain of SARS-CoV-2.

\section{Phenotyping SARS-CoV-2-specific B cells subsets}

We collected a single blood sample from three PCRconfirmed SARS-CoV-2-infected individuals (COSCA1-3) approximately four weeks after symptom onset. COSCA1 (47year-old male) and COSCA2 (44-year-old female) showed symptoms of an upper respiratory tract infection and mild pneumonia, respectively (Table 1). Both remained in homeisolation during the course of COVID-19 symptoms. COSCA3, a 69-year-old male, developed a severe pneumonia and became respiratory-insufficient one and a half weeks after symptom onset, requiring admission to the intensive care unit for mechanical ventilation. To identify S protein-specific antibodies in serum, we generated soluble prefusion-stabilized S proteins of SARS-CoV-2 using stabilization strategies as previously described for $\mathrm{S}$ proteins of SARS-CoV-2 and other $\beta$-coronaviruses (Fig. 1A) (12, 34). As demonstrated by the size-exclusion chromatography (SEC) trace, SDS- and blue-native PAGE, the resulting trimeric SARS-CoV-2 S proteins were of high purity (fig. S1, A and B). Sera from all patients showed strong binding to the $\mathrm{S}$ protein of SARS-CoV-2 in an enzyme-linked immunosorbent assay (ELISA) with endpoint titers of 13637,6133 , and 48120 for COSCA1, COSCA2 and COSCA3, respectively (Fig. 1B) and showed cross-reactivity to the S protein of SARS-CoV (fig. S1C). COSCA1-3 had varying neutralizing potencies against SARS-CoV-2 pseudovirus with $50 \%$ inhibition of virus infection $\left(\mathrm{ID}_{50}\right.$ ) of 383,626 and 7645, respectively (Fig. 1C) and similar activities against authentic virus (fig. S1D). In addition, all sera showed crossneutralization of SARS-CoV pseudovirus and authentic SARS$\mathrm{CoV}$ virus, albeit with low potency (fig. S1, E and F). The potent $\mathrm{S}$ protein binding and neutralizing responses observed for COSCA3 are in line with earlier findings that severe disease is associated with a strong humoral response (35). Based on these strong serum binding and neutralization titers, we sorted SARS-CoV-2 S protein-specific B cells for $\mathrm{mAb}$ isolation from COSCA1-3.

Peripheral blood mononuclear cells (PBMCs) were stained dually with fluorescently labeled prefusion SARS-CoV-2 S proteins and analyzed for the frequency and phenotype of specific B cells by flow cytometry (Fig. 2A and fig S2). The analysis revealed a frequency ranging from $0.68-1.74 \%$ of $\mathrm{S}$ protein-specific B cells (S-AF647 $7^{+}$S-BV421 $)$among the total pool of B cells (CD19+Via-CD3-CD14-CD16), (Fig. 2B). These SARS-CoV-2 S-specific B cells showed a predominant memory $\left(\mathrm{CD} 20^{+} \mathrm{CD} 27^{+}\right)$and plasmablasts/plasma cell (PB/PC) $\left(\mathrm{CD} 20^{-}\right.$ $\mathrm{CD} 27^{+} \mathrm{CD} 38^{+}$) phenotype. We observed a three-fold higher percentage of $\mathrm{PB} / \mathrm{PCs}$ for SARS-CoV-2 S-specific B cells in comparison to total B cells ( $p=0.034)$, indicating an enrichment of specific B cells in this subpopulation (Fig. 2C). COSCA3, who experienced severe symptoms, showed the highest frequency of $\mathrm{PB} / \mathrm{PC}$ in both total (34\%) and specific (60\%) B-cells (Fig. 2C and fig. S2). As expected, the SARS-CoV$2 \mathrm{~S}$ protein-specific B cells were enriched in the $\mathrm{IgG}^{+}$and $\mathrm{IgM}^{-}$ /IgG- (most likely representing IgA ${ }^{+}$) B cell populations, although a substantial portion of the specific B cells were IgM $^{+}$, particularly for COSCA3 (Fig. 2D). 


\section{Genotypic signatures of the SARS-CoV-2-specific anti- body response}

SARS-CoV-2 S-specific B cells were subsequently single cell sorted for sequencing and mAb isolation. In total, 409 heavy chain $(\mathrm{HC})$ and light chain (LC) pairs were obtained from the sorted B cells of the three patients $(137,165$, and 107 from COSCA1-3, respectively), of which 323 were unique clonotypes. Clonal expansion occurred in all three patients (Fig. $3 \mathrm{~A})$, but was strongest in COSCA3 where it was dominated by $\mathrm{HC}$ variable $(\mathrm{VH})$ regions $\mathrm{VH} 3-7$ and $\mathrm{VH} 4-39$ (34\% and $32 \%$ of SARS-CoV-2 S-specific sequences, respectively). Even though substantial clonal expansion occurred in COSCA3, the median somatic hypermutation (SHM) was $1.4 \%$, with similar SHM in COSCA1 and COSCA2 (2.1\% and 1.4\%) (Fig. 3B). These SHM levels are similar to those observed in response to infection with other respiratory viruses (36).

A hallmark of antibody diversity is the heavy chain complementarity determining region 3 (CDRH3). Since the CDRH3 is composed of $\mathrm{V}, \mathrm{D}$ and $\mathrm{J}$ gene segments, it is the most variable region of an antibody in terms of both amino acid composition and length. The average length of CDRH3 in the naive human repertoire is 15 amino acids (37), but for a subset of influenza virus and HIV-1 broadly neutralizing antibodies, long CDRH3 regions of 20-35 amino acids are crucial for high affinity antigen-antibody interactions $(38,39)$. Even though the mean CDRH3 length of isolated SARS-CoV$2 \mathrm{~S}$ protein-specific B cells did not differ substantially from that of a naive population (37), we observed a significant difference in the distribution of CDRH3 length (two sample Kolmogorov-Smirnov test, $p=0.006$ ) (Fig. 3C). This difference in CDRH3 distribution can largely be attributed to an enrichment of longer ( 20 amino acid) CDRH3s, leading to a bimodal distribution as opposed to a bell-shaped distribution that was observed in the naive repertoire (Fig. 3C and fig. S3).

Next, to determine SARS-CoV-2-specific signatures in B cell receptor (BCR) repertoire usage, we compared ImmunoGenetics (IMGT)-database assigned unique germline $\mathrm{V}$ regions from the sorted SARS-CoV-2 S-specific B cells to the well-defined extensive germline repertoire in the naive population (Fig. 3D) (37). Multiple VH genes were enriched in COSCA1-3 patients compared to the naive repertoire, including VH3-33 ( $p=0.009)$ and VH1-24 ( $p<0.001)$ (Fig. 3D). Even though the enrichment of VH1-69 was not significant ( $p>$ 0.05), it should be noted that an enrichment of VH1-69 has been shown in response to a number of other viral infections, including influenza virus, hepatitis $\mathrm{C}$ virus and rotavirus (40), and an enrichment of VH3-33 was observed in response to malaria vaccination, whereas the enrichment of VH1-24 appears to be specific for COVID-19 (Fig. 3D) (41). In contrast, VH4-34 $(p>0.05)$ and VH3-23 ( $p=0.018)$ were substantially underrepresented in SARS-CoV-2-specific sequences compared to the naive population. While the usage of most $\mathrm{VH}$ genes was consistent between COVID-19 patients, particularly VH3-30-3 and VH4-39 showed considerable variability. Thus, upon SARS-CoV-2 infection the S protein recruits a subset of $\mathrm{B}$ cells from the naive repertoire enriched in specific VH segments and CDRH3 domains.

\section{Identification of unusually potent SARS-CoV-2 neutral- izing antibodies}

Subsequently, all HC and LC pairs were transiently expressed in HEK 293T cells and screened for binding to SARS-CoV-2 S protein by ELISA. $84 \mathrm{mAbs}$ that showed high affinity binding were selected for small-scale expression in HEK $293 \mathrm{~F}$ cells and purified (table S1). We obtained few S protein-reactive mAbs from COSCA3, possibly because most B cells from this individual were IgM+ $\mathrm{I}^{+}$, while cloning into an IgG backbone nullified avidity contributions to binding and neutralization present in the serum. To gain insight in the immunodominance of the RBD as well as the ability to cross-react with SARS-CoV, we assessed the binding capacity of these mAbs to the prefusion S proteins and the RBDs of SARS-CoV-2 and SARS-CoV by ELISA. Of the $84 \mathrm{mAbs}$ that were tested, 32 (38\%) bound to the SARS-CoV-2 RBD (Fig. 4, A and B) with 7 mAbs (22\%) showing cross-binding to SARS-CoV RBD (fig. S4A). Interestingly, we also observed $33 \mathrm{mAbs}(39 \%)$ that bound strongly to SARS-CoV-2 S but did not bind the RBD, of which 10 mAbs (30\%) also bound to the S protein of SARS$\mathrm{CoV}$ (Fig. 4, A and B). Notably, some mAbs that bound very weakly to soluble SARS-CoV-2 S protein in ELISA showed strong binding to membrane-bound $S$ protein, implying that their epitopes are presented poorly on the stabilized soluble $\mathrm{S}$ protein or that avidity is important for their binding (table S1). Surface plasmon resonance (SPR) assays confirmed binding of $77 \mathrm{mAbs}$ to $\mathrm{S}$ protein and $21 \mathrm{mAbs}$ to the RBD with binding affinities in the nano- to picomolar range (table $\mathrm{S} 1$ ).

All 84 mAbs were subsequently tested for their ability to block infection. $19 \mathrm{mAbs}$ (23\%) inhibited SARS-CoV-2 pseudovirus infection with varying potencies (Fig. 4C), of these 14 (74\%) bind the RBD. Seven of the 19 mAbs could be categorized as potent neutralizers $\left(\mathrm{IC}_{50}<0.1 \mu \mathrm{g} / \mathrm{mL}\right.$ ), six as moderate $\left(\mathrm{IC}_{50}\right.$ of $\left.0.1-1 \mu \mathrm{g} / \mathrm{mL}\right)$ and six as weak neutralizers $\left(\mathrm{IC}_{50}\right.$ of 1-10 $\mu \mathrm{g} / \mathrm{mL}$ ). With $\mathrm{IC}_{50} \mathrm{~S}$ of $0.008 \mu \mathrm{g} / \mathrm{mL}$, the RBD-targeting antibodies COVA1-18 and COVA2-15, in particular, were unusually potent. However, they were quite different in other aspects such as their heavy chain V gene usage (VH3-66 vs. VH3-23), light chain usage (VL7-46 vs. VK2-30), HC sequence identity (77\%) and CDRH3 length (12 vs. 22 amino acids). 17 of the mAbs also interacted with the SARS-CoV S and RBD proteins and two of these cross-neutralized the SARS-CoV pseudovirus $\left(\mathrm{IC}_{50}\right.$ of $2.5 \mu \mathrm{g} / \mathrm{mL}$ for COVA1- 16 and $0.61 \mu \mathrm{g} / \mathrm{mL}$ for COVA2-02; fig. S4B), with COVA2-02 being more potent against SARS-CoV than against SARS-CoV-2. Next, we assessed the ability of the 19 mAbs to block infection of 
authentic SARS-CoV-2 virus (Fig. 4C and fig. S4C). While previous reports suggest a decrease in neutralization sensitivity of primary SARS-CoV-2 in comparison to pseudovirus $(25,27$, 28 ), we observed very similar potencies for 7 out of the 19 NAbs including the most potent NAbs $\left(\mathrm{IC}_{50} \mathrm{~S}\right.$ of 0.007 and $0.009 \mu \mathrm{g} / \mathrm{mL}$ for COVA1-18 and COVA2-15, respectively; Fig. 4C). NAbs COVA1-18, COVA2-04, COVA2-07, COVA2-15, and COVA2-39 also showed strong competition with ACE2 binding, illustrating that blocking ACE2 binding is their likely mechanism of neutralization (fig. S4D). The RBD-targeting mAb COVA2-17 however showed incomplete competition with ACE2. This corroborates previous observations that the $\mathrm{RBD}$ encompasses multiple distinct antigenic sites some of which do not block ACE2 binding $(23,25,26)$. Interestingly, the non-RBD NAbs all bear substantially longer CDRH3s compared to RBD NAbs (fig. S4E), suggesting a convergent CDRH3-dependent contact between antibody and epitope.

\section{Multiple targets of vulnerability on the SARS-CoV-2 spike protein}

To identify and characterize the antigenic sites on the S protein and their interrelationships we performed SPR-based cross-competition assays using $\mathrm{S}$ protein followed by clustering analysis. We note that competition clusters do not necessarily equal epitope clusters, but the analysis can provide clues on the relation of mAb epitopes. We identified $11 \mathrm{com}-$ petition clusters of which nine contained more than one $\mathrm{mAb}$ while two contained only one mAb (clusters X and XI; Fig. $5 \mathrm{~A}$ and fig. S5). All nine multiple-mAb clusters included mAbs from at least two of the three patients, emphasizing that these clusters represent common epitopes targeted by the human humoral immune response during SARS-CoV-2 infection. Three clusters included predominantly RBD-binding mAbs (clusters I, III, VII), with cluster I forming two subclusters. These three clusters were confirmed by performing crosscompetition experiments with soluble RBD instead of complete S protein (fig. S5B). Four clusters (V, VI, XIII and IX) included predominantly $\mathrm{mAbs}$ that did not interact with RBD, and clusters II, IV, X and XI consisted exclusively of non-RBD mAbs. mAbs with diverse phenotypes (e.g., RBD and non-RBD binding mAbs) clustered together in multiple clusters, suggesting that these mAbs might target epitopes bridging the RBD and non-RBD sites or that they sterically interfere with each other's binding as opposed to binding to overlapping epitopes. While clusters II, V and VIII contained only mAbs incapable of neutralizing SARS-CoV-2, clusters I, III, IV, VI and VII included both non-NAbs and NAbs. Interestingly, cluster $\mathrm{V}$ was formed mostly by non-RBD targeting mAbs that also bounnd to SARS-CoV. However, these mAbs were not able to neutralize either SARS-CoV-2 or SARS-CoV, suggesting that these mAbs target a conserved non-neutralizing epitope on the $\mathrm{S}$ protein. Finally, the two non-RBD mAbs
COVA1-03 and COVA1-21 formed single-mAb competition clusters (cluster $\mathrm{X}$ and XI, respectively) and showed an unusual competition pattern, as binding of either mAb blocked binding by majority of the other mAbs, but not vice versa (figs. S5 and S6 and table S2). We hypothesize that these two mAbs allosterically interfere with mAb binding by causing conformational changes in the $\mathrm{S}$ protein that shield or impair the majority of other mAb epitopes. COVA1-21 also efficiently blocked virus infection, without blocking ACE2, suggesting an alternative mechanism of neutralization than blocking ACE2 engagement (fig. S4C). The SPR-based clustering was corroborated by using bio-layer interferometry competition assays on a subset of NAbs (fig. S6). Overall, our data are consistent with the previous identification of multiple antigenic RBD sites for SARS-CoV-2 and additional non-RBD sites on the $\mathrm{S}$ protein as described for SARS-CoV and MERS-CoV (32, 42).

To visualize how selected NAbs bound to their respective epitopes, we generated Fab-SARS-CoV-2 S complexes that were imaged by single particle negative-stain electron microscopy (NS-EM; Fig. 5, B and C, and fig. S7). We obtained low-resolution reconstruction with six Fabs, including five RBD-binding Fabs from three different competition clusters. COVA1-12 is highly overlapping with the epitope of COVA239, while COVA2-04 approaches the RBD at a different angle that is somewhat similar to the cross-binding SARS-CoVspecific mAbs CR3022 (42). The EM reconstructions confirmed the RBD as the target of these NAbs, but revealed a diversity in approach angles (Fig. 5B). Furthermore, while four RBD NAbs interacted with a stoichiometry of one Fab per trimer, consistent with one RBD being exposed in the "up state" and two in the less accessible "down state" $(13,43)$, COVA2-15 bound with a stoichiometry of three per trimer (fig. S7). Strikingly, COVA2-15 is able to bind RBD domains in both the up or down state (Fig. 5D). In either conformation the COVA2-15 epitope partially overlaps with the ACE2 binding site and therefore the mAb blocks receptor engagement. The higher stoichiometry of this mAb may explain its unusually strong neutralization potency. None of the epitopes of the five RBD Fabs overlapped with that of CR3022 which is unable to neutralize SARS-CoV-2 (42), although COVA2-04 does approach the RBD from a similar angle as CR3022. The sixth Fab for which we generated a $3 \mathrm{D}$ reconstruction was from the non-RBD mAb COVA1-22, placed in competition cluster IX. The EM demonstrated that this mAb bound to the $\mathrm{N}$-terminal domain (NTD) of S1. Such NTD NAbs have been found for MERS-CoV (44).

\section{Conclusions}

Convalescent COVID-19 patients showed strong anti-SARSCoV-2 S protein specific B cell responses and developed memory and antibody producing $\mathrm{B}$ cells that may have 
participated in the control of infection and the establishment of humoral immunity. We isolated 19 NAbs that target a diverse range of antigenic sites on the $\mathrm{S}$ protein, of which two showed picomolar neutralizing activities $\left(\mathrm{IC}_{50} \mathrm{~S}\right.$ of 0.007 and $0.009 \mathrm{\mu g} / \mathrm{mL}$ or 47 and $60 \mathrm{pM}$ ) against authentic SARS-CoV2 virus. This illustrates that SARS-CoV-2 infection elicits high-affinity and cross-reactive mAbs targeting the RBD as well as other sites on the S protein. Several of the potent NAbs had VH segments virtually identical to their germline origin, which holds promise for the induction of similar NAbs by vaccination as extensive affinity maturation does not appear to be a requirement for potent neutralization. Interestingly, the most potent NAbs both target the RBD on the S protein and fall within the same competition cluster, but are isolated from two different individuals and bear little resemblance genotypically. Although direct comparisons are difficult, the neutralization potency of these and several other mAbs exceeds the potencies of the most advanced HIV-1 and Ebola mAbs under clinical evaluation as well as approved anti-RSV mAb palivizumab (45). Through large-scale SPR-based competition assays, we defined NAbs that target multiple sites of vulnerability on the RBD as well as additional previously undefined non-RBD epitopes on SARS-CoV-2. This is consistent with the identification of multiple antigenic RBD sites for SARS-CoV-2 and the presence of additional non-RBD sites on the S protein of SARS-CoV and MERS-CoV (32). Subsequent structural characterization of these potent NAbs will guide vaccine design, while simultaneous targeting of multiple nonRBD and RBD epitopes with mAb cocktails paves the way for safe and effective COVID-19 prevention and treatment.

\section{REFERENCES AND NOTES}

1. E. Dong, H. Du, L. Gardner, An interactive web-based dashboard to track COVID-19 in real time. Lancet Infect. Dis. 20, 533-534 (2020). doi:10.1016/S14733099(20)30120-1 Medline

2. N. Chen, M. Zhou, X. Dong, J. Qu, F. Gong, Y. Han, Y. Qiu, J. Wang, Y. Liu, Y. Wei, J. Xia, T. Yu, X. Zhang, L. Zhang, Epidemiological and clinical characteristics of 99 cases of 2019 novel coronavirus pneumonia in Wuhan, China: A descriptive study. Lancet 395, 507-513 (2020). doi:10.1016/S0140-6736(20)30211-7 Medline

3. J. Mair-Jenkins, M. Saavedra-Campos, J. K. Baillie, P. Cleary, F.-M. Khaw, W. S. Lim, S. Makki, K. D. Rooney, J. S. Nguyen-Van-Tam, C. R. Beck; Convalescent Plasma Study Group. The effectiveness of convalescent plasma and hyperimmune immunoglobulin for the treatment of severe acute respiratory infections of viral etiology: A systematic review and exploratory meta-analysis. J. Infect. Dis. 211, 80-90 (2015). doi:10.1093/infdis/jiu396 Medline

4. J. H. Ko, H. Seok, S. Y. Cho, Y. E. Ha, J. Y. Baek, S. H. Kim, Y. J. Kim, J. K. Park, C. R. Chung, E.-S. Kang, D. Cho, M. A. Müller, C. Drosten, C.-I. Kang, D. R. Chung, J.-H. Song, K. R. Peck, Challenges of convalescent plasma infusion therapy in Middle East respiratory coronavirus infection: A single centre experience. Antivir. Ther. 23, 617-622 (2018). doi:10.3851//MP3243 Medline

5. C. Shen, Z. Wang, F. Zhao, Y. Yang, J. Li, J. Yuan, F. Wang, D. Li, M. Yang, L. Xing, J. Wei, H. Xiao, Y. Yang, J. Qu, L. Qing, L. Chen, Z. Xu, L. Peng, Y. Li, H. Zheng, F. Chen, K. Huang, Y. Jiang, D. Liu, Z. Zhang, Y. Liu, L. Liu, Treatment of 5 critically ill patients with COVID-19 with convalescent plasma. JAMA 323, 1582 (2020). doi:10.1001/jama.2020.4783 Medline

6. R. Kulkarni, in Dynamics of Immune Activation in Viral Diseases, P. V. Bramhachari, Ed. (Springer, 2020), pp. 9-41.

7. S. Mulangu, L. E. Dodd, R. T. Davey Jr., O. Tshiani Mbaya, M. Proschan, D. Mukadi,
M. Lusakibanza Manzo, D. Nzolo, A. Tshomba Oloma, A. Ibanda, R. Ali, S. Coulibaly, A. C. Levine, R. Grais, J. Diaz, H. C. Lane, J.-J. Muyembe-Tamfum, B. Sivahera, M. Camara, R. Kojan, R. Walker, B. Dighero-Kemp. H. Cao, P. Mukumbayi, P. MbalaKingebeni, S. Ahuka, S. Albert, T. Bonnett, I. Crozier, M. Duvenhage, C. Proffitt, M. Teitelbaum, T. Moench, J. Aboulhab, K. Barrett, K. Cahill, K. Cone, R. Eckes, L. Hensley, B. Herpin, E. Higgs, J. Ledgerwood, J. Pierson, M. Smolskis, Y. Sow, J. Tierney, S. Sivapalasingam, W. Holman, N. Gettinger, D. Vallée, J. Nordwall; PALM Writing Group; PALM Consortium Study Team, A randomized, controlled trial of Ebola virus disease therapeutics. N. Engl. J. Med. 381, 2293-2303 (2019). doi:10.1056/NEJMoa1910993 Medline

8. J. van Griensven, T. Edwards, X. de Lamballerie, M. G. Semple, P. Gallian, S. Baize, P. W. Horby, H. Raoul, N. Magassouba, A. Antierens, C. Lomas, O. Faye, A. A. Sall, K. Fransen, J. Buyze, R. Ravinetto, P. Tiberghien, Y. Claeys, M. De Crop, L. Lynen, E. I. Bah, P. G. Smith, A. Delamou, A. De Weggheleire, N. Haba; Ebola-Tx Consortium, Evaluation of convalescent plasma for Ebola virus disease in Guinea. N. Engl. J. Med. 374, 33-42 (2016). doi:10.1056/NEJMoa1511812 Medline

9. E. Hershberger, S. Sloan, K. Narayan, C. A. Hay, P. Smith, F. Engler, R. Jeeninga, S. Smits, J. Trevejo, Z. Shriver, D. Oldach, Safety and efficacy of monoclonal antibody VIS410 in adults with uncomplicated influenza A infection: Results from a randomized, double-blind, phase-2, placebo-controlled study. EBioMedicine 40 , 574-582 (2019). doi:10.1016/i.ebiom.2018.12.051 Medline

10. N. J. Gogtay, R. Munshi, D. H. Ashwath Narayana, B. J. Mahendra, V. Kshirsagar, B. Gunale, S. Moore, P. Cheslock, S. Thaker, S. Deshpande, S. Karande, D. Kumbhar H. S. Ravish, B. R. Harish, S. S. Pisal, R. Dhere, V. Parulekar, W. C. Blackwelder, D. C. Molrine, P. S. Kulkarni, Comparison of a novel human rabies monoclonal antibody to human rabies immunoglobulin for postexposure prophylaxis: A phase $2 / 3$, randomized, single-blind, noninferiority, controlled study. Clin. Infect. Dis. 66, 387-395 (2018). doi:10.1093/cid/cix791 Medline

11. T. Sandritter, Palivizumab for respiratory syncytial virus prophylaxis. J. Pediatr. Health Care 13, 191-195, quiz 196-197 (1999). doi:10.1016/S0891-5245(99)90039-1 Medline

12. D. Wrapp, N. Wang, K. S. Corbett, J. A. Goldsmith, C.-L. Hsieh, O. Abiona, B. S. Graham, J. S. McLellan, Cryo-EM structure of the 2019-nCoV spike in the prefusion conformation. Science 367, 1260-1263 (2020). doi:10.1126/science.abb2507 Medline

13. A. C. Walls, Y.-J. Park, M. A. Tortorici, A. Wall, A. T. McGuire, D. Veesler, Structure, function, and antigenicity of the SARS-CoV-2 spike glycoprotein. Cell 181, 281292.e6 (2020). doi:10.1016/i.cell.2020.02.058 Medline

14. F. Li, Structure, function, and evolution of coronavirus spike proteins. Annu. Rev. Virol. 3, 237-261 (2016). doi:10.1146/annurev-virology-110615-042301 Medline

15. J. Shang, G. Ye, K. Shi, Y. Wan, C. Luo, H. Aihara, Q. Geng, A. Auerbach, F. Li, Structural basis of receptor recognition by SARS-CoV-2. Nature 581, 221-224 (2020). doi:10.1038/s41586-020-2179-y Medline

16. R. W. Sanders, R. Derking, A. Cupo, J.-P. Julien, A. Yasmeen, N. de Val, H. J. Kim, C. Blattner, A. T. de la Peña, J. Korzun, M. Golabek, K. de Los Reyes, T. J. Ketas, M. J. van Gils, C. R. King, I. A. Wilson, A. B. Ward, P. J. Klasse, J. P. Moore, A nextgeneration cleaved, soluble HIV-1 Env trimer, BG505 SOSIP.664 gp140, expresses multiple epitopes for broadly neutralizing but not non-neutralizing antibodies. PLOS Pathog. 9, e1003618 (2013). doi:10.1371/journal.ppat.1003618 Medline

17. J. E. Robinson, K. M. Hastie, R. W. Cross, R. E. Yenni, D. H. Elliott, J. A. Rouelle, C. B. Kannadka, A. A. Smira, C. E. Garry, B. T. Bradley, H. Yu, J. G. Shaffer, M. L. Boisen, J. N. Hartnett, M. A. Zandonatti, M. M. Rowland, M. L. Heinrich, L. MartínezSobrido, B. Cheng, J. C. de la Torre, K. G. Andersen, A. Goba, M. Momoh, M. Fullah, M. Gbakie, L. Kanneh, V. J. Koroma, R. Fonnie, S. C. Jalloh, B. Kargbo, M. A. Vandi, M. Gbetuwa, O. Ikponmwosa, D. A. Asogun, P. O. Okokhere, O. A. Follarin, J. S. Schieffelin, K. R. Pitts, J. B. Geisbert, P. C. Kulakoski, R. B. Wilson, C. T. Happi, P. C. Sabeti, S. M. Gevao, S. H. Khan, D. S. Grant, T. W. Geisbert, E. O. Saphire, L. M. Branco, R. F. Garry, Most neutralizing human monoclonal antibodies target novel epitopes requiring both Lassa virus glycoprotein subunits. Nat. Commun. 7, 11544 (2016). doi:10:1038/ncomms11544 Medline

18. S. Jiang, C. Hillyer, L. Du, Neutralizing antibodies against SARS-CoV-2 and other human coronaviruses. Trends Immunol. 41, 355-359 (2020). do: 10.1016/i.it.2020.03.007 Medline

19. J. S. McLellan, W. C. Ray, M. E. Peeples, Structure and function of respiratory syncytial virus surface glycoproteins. Curr. Top. Microbiol. Immunol. 372, 83-104 
(2013). doi:10.1007/978-3-642-38919-1 4 Medline

20. D. Sok, M. J. van Gils, M. Pauthner, J.-P. Julien, K. L. Saye-Francisco, J. Hsueh, B. Briney, J. H. Lee, K. M. Le, P. S. Lee, Y. Hua, M. S. Seaman, J. P. Moore, A. B. Ward, I. A. Wilson, R. W. Sanders, D. R. Burton, Recombinant HIV envelope trimer selects for quaternary-dependent antibodies targeting the trimer apex. Proc. Natl. Acad. Sci. U.S.A. 111, 17624-17629 (2014). doi:10.1073/pnas.1415789111 Medline

21. X. Tian, C. Li, A. Huang, S. Xia, S. Lu, Z. Shi, L. Lu, S. Jiang, Z. Yang, Y. Wu, T. Ying, Potent binding of 2019 novel coronavirus spike protein by a SARS coronavirusspecific human monoclonal antibody. Emerg. Microbes Infect. 9, 382-385(2020). doi:10.1080/22221751.2020.1729069 Medline

22. C. Wang, W. Li, D. Drabek, N. M. A. Okba, R. van Haperen, A. D. M. E. Osterhaus, F. J. M. van Kuppeveld, B. L. Haagmans, F. Grosveld, B.-J. Bosch, A human monoclonal antibody blocking SARS-CoV-2 infection. Nat. Commun. 11, 2251 (2020). doi:10.1038/s41467-020-16256-y Medline

23. D. Pinto, Y.-J. Park, M. Beltramello, A. C. Walls, M. A. Tortorici, S. Bianchi, S. Jaconi, K. Culap, F. Zatta, A. De Marco, A. Peter, B. Guarino, R. Spreafico, E. Cameroni, J. B. Case, R. E. Chen, C. Havenar-Daughton, G. Snell, A. Telenti, H. W. Virgin, A. Lanzavecchia, M. S. Diamond, K. Fink, D. Veesler, D. Corti, Structural and functional analysis of a potent Sarbecovirus neutralizing antibody. bioRxiv 2020.04.07.023903 [Preprint]. 10 April 2020); https://doi.org/10.1101/2020.04.07.023903.

24. X. Chen, R. Li, Z. Pan, C. Qian, Y. Yang, R. You, J. Zhao, P. Liu, L. Gao, Z. Li, Q. Huang, L. Xu, J. Tang, Q. Tian, W. Yao, L. Hu, X. Yan, X. Zhou, Y. Wu, K. Deng, Z. Zhang, Z. Qian, Y. Chen, L. Ye, Human monoclonal antibodies block the binding of SARSCoV-2 spike protein to angiotensin converting enzyme 2 receptor. Cell. Mol. Immunol. 17, 647-649 (2020). doi:10.1038/s41423-020-0426-7 Medline

25. S. J. Zost, P. Gilchuk, J. B. Case, E. Binshtein, R. E. Chen, J. X. Reidy, A. Trivette, R. S. Nargi, R. E. Sutton, N. Suryadevara, L. E. Williamson, E. C. Chen, T. Jones, S. Day, L. Myers, A. O. Hassan, N. M. Kafai, E. S. Winkler, J. M. Fox, J. J. Steinhardt, K. Ren, Y.-M. Loo, N. L. Kallewaard, D. R. Martinez, A. Schäfer, L. E. Gralinski, R. S. Baric, L. B. Thackray, M. S. Diamond, R. H. Carnahan, J. E. Crowe Jr., Potently neutralizing human antibodies that block SARS-CoV-2 receptor binding and protect animals. bioRxiv 2020.05.22.111005 [Preprint]. 22 May 2020; https://doi.org/10.1101/2020.05.22.111005.

26. D. F. Robbiani, C. Gaebler, F. Muecksch, J. C. C. Lorenzi, Z. Wang, A. Cho, M. Agudelo, C. O. Barnes, A. Gazumyan, S. Finkin, T. Hagglof, T. Y. Oliveira, C. Viant, A. Hurley, H.-H. Hoffmann, K. G. Millard, R. G. Kost, M. Cipolla, K. Gordon, F. Bianchini, S. T. Chen, V. Ramos, R. Patel, J. Dizon, I. Shimeliovich, P. Mendoza, H. Hartweger, L. Nogueira, M. Pack, J. Horowitz, F. Schmidt, Y. Weisblum, E. Michailidis, A. W. Ashbrook, E. Waltari, J. E. Pak, K. E. Huey-Tubman, N. Koranda, P. R. Hoffman, A. P. West Jr., C. M. Rice, T. Hatziioannou, P. J. Bjorkman, P. D. Bieniasz, M. Caskey, M. C. Nussenzweig, Convergent antibody responses to SARS-CoV-2 infection in convalescent individuals. bioRxiv 2020.05.13.092619 [Preprint]. 22 May 2020; https://doi.org/10.1101/2020.05.13.092619.

27. B. Ju, Q. Zhang, J. Ge, R. Wang, J. Sun, X. Ge, J. Yu, S. Shan, B. Zhou, S. Song, X. Tang, J. Yu, J. Lan, J. Yuan, H. Wang, J. Zhao, S. Zhang, Y. Wang, X. Shi, L. Liu, J. Zhao, X. Wang, Z. Zhang, L. Zhang, Human neutralizing antibodies elicited by SARS-CoV-2 infection. Nature (2020). doi:10.1038/s41586-020-2380-z Medline

28. T. F. Rogers, F. Zhao, D. Huang, N. Beutler, A. Burns, W. He, O. Limbo, C. Smith, G Song, J. Woehl, L. Yang, R. K. Abbott, S. Callaghan, E. Garcia, J. Hurtado, M. Parren, L. Peng, J. Ricketts, M. J. Ricciardi, S. A. Rawlings, D. M. Smith, D. Nemazee, J. R. Teijaro, J. E. Voss, R. Andrabi, B. Briney, E. Landais, D. Sok, J. G. Jardine, D. R. Burton, Rapid isolation of potent SARS-CoV-2 neutralizing antibodies and protection in a small animal model. bioRxiv 2020.05.11.088674 [Preprint]. 15 May 2020; https://doi.org/10.1101/2020.05.11.088674.

29. X. C. Tang, S. S. Agnihothram, Y. Jiao, J. Stanhope, R. L. Graham, E. C. Peterson, Y. Avnir, A. S. C. Tallarico, J. Sheehan, Q. Zhu, R. S. Baric, W. A. Marasco, Identification of human neutralizing antibodies against MERS-CoV and their role in virus adaptive evolution. Proc. Natl. Acad. Sci. U.S.A. 111, E2018-E2026 (2014). doi:10.1073/pnas.1402074111 Medline

30. J. ter Meulen, E. N. van den Brink, L. L. M. Poon, W. E. Marissen, C. S. W. Leung, F. Cox, C. Y. Cheung, A. Q. Bakker, J. A. Bogaards, E. van Deventer, W. Preiser, H. W. Doerr, V. T. Chow, J. de Kruif, J. S. M. Peiris, J. Goudsmit, Human monoclonal antibody combination against SARS coronavirus: Synergy and coverage of escape mutants. PLOS Med. 3, e237 (2006). doi:10.1371/journal.pmed.0030237Medline
31. M. Grobben, R. A. Stuart, M. J. van Gils, The potential of engineered antibodies for HIV-1 therapy and cure. Curr. Opin. Virol. 38, 70-80 (2019). doi:10.1016/i.coviro.2019.07.007 Medline

32. B. Shanmugaraj, K. Siriwattananon, K. Wangkanont, W. Phoolcharoen, Perspectives on monoclonal antibody therapy as potential therapeutic intervention for Coronavirus disease-19 (COVID-19). Asian Pac. J. Allergy Immunol. 38, 10-18 (2020). Medline

33. S. F. Ahmed, A. A. Quadeer, M. R. McKay, Preliminary identification of potential vaccine targets for the COVID-19 coronavirus (SARS-CoV-2) based on SARS-CoV immunological studies. Viruses 12, 254 (2020). doi:10.3390/v12030254 Medline

34. J. Pallesen, N. Wang, K. S. Corbett, D. Wrapp, R. N. Kirchdoerfer, H. L. Turner, C. A. Cottrell, M. M. Becker, L. Wang, W. Shi, W.-P. Kong, E. L. Andres, A. N. Kettenbach, M. R. Denison, J. D. Chappell, B. S. Graham, A. B. Ward, J. S. McLellan, Immunogenicity and structures of a rationally designed prefusion MERS-CoV spike antigen. Proc. Natl. Acad. Sci. U.S.A. 114, E7348-E7357 (2017). doi:10.1073/pnas.1707304114 Medline

35. J. Zhao, Q. Yuan, H. Wang, W. Liu, X. Liao, Y. Su, X. Wang, J. Yuan, T. Li, J. Li, S. Qian, C. Hong, F. Wang, Y. Liu, Z. Wang, Q. He, Z. Li, B. He, T. Zhang, Y. Fu, S. Ge, L. Liu, J. Zhang, N. Xia, Z. Zhang, Antibody responses to SARS-CoV-2 in patients of novel coronavirus disease 2019. Clin. Infect. Dis. ciaa344 (2020). doi:10.1093/cid/ciaa344 Medline

36. E. Goodwin, M. S. A. Gilman, D. Wrapp, M. Chen, J. O. Ngwuta, S. M. Moin, P. Bai, A. Sivasubramanian, R. I. Connor, P. F. Wright, B. S. Graham, J. S. McLellan, L. M. Walker, Infants infected with respiratory syncytial virus generate potent neutralizing antibodies that lack somatic hypermutation. Immunity 48, 339349.e5 (2018). doi:10.1016/i.immuni.2018.01.005 Medline

37. B. Briney, A. Inderbitzin, C. Joyce, D. R. Burton, Commonality despite exceptional diversity in the baseline human antibody repertoire. Nature 566, 393-397 (2019). doi:10.1038/s41586-019-0879-y Medline

38. N. C. Wu, G. Grande, H. L. Turner, A. B. Ward, J. Xie, R. A. Lerner, I. A. Wilson, In vitro evolution of an influenza broadly neutralizing antibody is modulated by hemagglutinin receptor specificity. Nat. Commun. 8, 15371 (2017). doi:10.1038/ncomms15371 Medline

39. L. Yu, Y. Guan, Immunologic basis for long HCDR3s in broadly neutralizing antibodies against HIV-1. Front. Immunol. 5, 250 (2014). do::10.3389/fimmu.2014.00250 Medline

40. F. Chen, N. Tzarum, I. A. Wilson, M. Law, VH1-69 antiviral broadly neutralizing antibodies: Genetics, structures, and relevance to rational vaccine design. Curr. Opin. Virol. 34, 149-159 (2019). doi:10.1016/i.coviro.2019.02.004 Medline

41. J. Tan, B. K. Sack, D. Oyen, I. Zenklusen, L. Piccoli, S. Barbieri, M. Foglierini, C. S. Fregni, J. Marcandalli, S. Jongo, S. Abdulla, L. Perez, G. Corradin, L. Varani, F. Sallusto, B. K. L. Sim, S. L. Hoffman, S. H. I. Kappe, C. Daubenberger, I. A. Wilson, A. Lanzavecchia, A public antibody lineage that potently inhibits malaria infection through dual binding to the circumsporozoite protein. Nat. Med. 24, 401-407 (2018). doi:10.1038/nm.4513 Medline

42. M. Yuan, N. C. Wu, X. Zhu, C. D. Lee, R. T. Y. So, H. Lv, C. K. P. Mok, I. A. Wilson, A highly conserved cryptic epitope in the receptor binding domains of SARS-CoV-2 and SARS-CoV. Science 368, 630-633 (2020). doi:10.1126/science.abb7269 Medline

43. Q. Wang, Y. Zhang, L. Wu, S. Niu, C. Song, Z. Zhang, G. Lu, C. Qiao, Y. Hu, K.-Y Yuen, Q. Wang, H. Zhou, J. Yan, J. Qi, Structural and functional basis of SARS-CoV2 entry by using human ACE2. Cell 181, 894-904.e9 (2020) doi:10.1016/i.cell.2020.03.045 Medline

44. N. Wang, O. Rosen, L. Wang, H. L. Turner, L. J. Stevens, K. S. Corbett, C. A. Bowman, J. Pallesen, W. Shi, Y. Zhang, K. Leung, R. N. Kirchdoerfer, M. M. Becker, M. R. Denison, J. D. Chappell, A. B. Ward, B. S. Graham, J. S. McLellan, Structural definition of a neutralization-sensitive epitope on the MERS-CoV S1-NTD. Cell Rep. 28, 3395-3405.e6 (2019). doi:10.1016/i.celrep.2019.08.052 Medline

45. K. E. Pascal, D. Dudgeon, J. C. Trefry, M. Anantpadma, Y. Sakurai, C. D. Murin, H. L. Turner, J. Fairhurst, M. Torres, A. Rafique, Y. Yan, A. Badithe, K. Yu, T. Potocky, S. L. Bixler, T. B. Chance, W. D. Pratt, F. D. Rossi, J. D. Shamblin, S. E. Wollen, J. M. Zelko, R. Carrion Jr., G. Worwa, H. M. Staples, D. Burakov, R. Babb, G. Chen, J. Martin, T. T. Huang, K. Erlandson, M. S. Willis, K. Armstrong, T. M. Dreier, A. B. Ward, R. A. Davey, M. L. M. Pitt, L. Lipsich, P. Mason, W. Olson, N. Stahl, C. A. Kyratsous, Development of clinical-stage human monoclonal antibodies that treat 
advanced Ebola virus disease in nonhuman primates. J. Infect. Dis. 218 (suppl. 5), S612-S626 (2018). doi:10.1093/infdis/iiy285 Medline

46. S. W. de Taeye, G. Ozorowski, A. Torrents de la Peña, M. Guttman, J.-P. Julien, T. L. G. M. van den Kerkhof, J. A. Burger, L. K. Pritchard, P. Pugach, A. Yasmeen, J. Crampton, J. Hu, I. Bontjer, J. L. Torres, H. Arendt, J. DeStefano, W. C. Koff, H. Schuitemaker, D. Eggink, B. Berkhout, H. Dean, C. LaBranche, S. Crotty, M. Crispin, D. C. Montefiori, P. J. Klasse, K. K. Lee, J. P. Moore, I. A. Wilson, A. B. Ward, R. W. Sanders, Immunogenicity of stabilized HIV-1 envelope trimers with reduced exposure of non-neutralizing epitopes. Cell 163, 1702-1715 (2015). doi:10.1016/i.cell.2015.11.056 Medline

47. T. Tiller, E. Meffre, S. Yurasov, M. Tsuiji, M. C. Nussenzweig, H. Wardemann, Efficient generation of monoclonal antibodies from single human $B$ cells by single cell RT-PCR and expression vector cloning. J. Immunol. Methods 329, 112-124 (2008). doi:10.1016/i.im.2007.09.017 Medline

48. M. J. van Gils, T. L. G. M. van den Kerkhof, G. Ozorowski, C. A. Cottrell, D. Sok, M. Pauthner, J. Pallesen, N. de Val, A. Yasmeen, S. W. de Taeye, A. Schorcht, S. Gumbs, I. Johanna, K. Saye-Francisco, C.-H. Liang, E. Landais, X. Nie, L. K. Pritchard, M. Crispin, G. Kelsoe, I. A. Wilson, H. Schuitemaker, P. J. Klasse, J. P. Moore, D. R. Burton, A. B. Ward, R. W. Sanders, An HIV-1 antibody from an elite neutralizer implicates the fusion peptide as a site of vulnerability. Nat. Microbiol. 2, 16199 (2016). doi:10.1038/nmicrobiol.2016.199 Medline

49. D. G. Gibson, L. Young, R.-Y. Chuang, J. C. Venter, C. A. Hutchison 3rd, H. O. Smith, Enzymatic assembly of DNA molecules up to several hundred kilobases. Nat. Methods 6, 343-345 (2009). do: 10.1038/nmeth.1318 Medline

50. R. I. Connor, B. K. Chen, S. Choe, N. R. Landau, Vpr is required for efficient replication of human immunodeficiency virus type- 1 in mononuclear phagocytes. Virology 206, 935-944 (1995). doi:10.1006/viro.1995.1016 Medline

51. N. M. A. Okba, M. A. Muller, W. Li, C. Wang, C. H. GeurtsvanKessel, V. M. Corman, M. M. Lamers, R. S. Sikkema, E. de Bruin, F. D. Chandler, Y. Yazdanpanah, Q. Le Hingrat, D. Descamps, N. Houhou-Fidouh, C. B. E. M. Reusken, B.-J. Bosch, C. Drosten, M. P. G. Koopmans, B. L. Haagmans, SARS-CoV-2 specific antibody responses in COVID-19 patients. medRxiv 2020.03.18.20038059 [Preprint] 20 March 2020; https://doi.org/10.1101/2020.03.18.20038059.

52. G. C. Lander, S. M. Stagg, N. R. Voss, A. Cheng, D. Fellmann, J. Pulokas, C. Yoshioka, C. Irving, A. Mulder, P.-W. Lau, D. Lyumkis, C. S. Potter, B. Carragher, Appion: An integrated, database-driven pipeline to facilitate EM image processing. J. Struct. Biol. 166, 95-102 (2009). doi:10.1016/i.jsb.2009.01.002 Medline

53. C. S. Potter, H. Chu, B. Frey, C. Green, N. Kisseberth, T. J. Madden, K. L. Miller, K. Nahrstedt, J. Pulokas, A. Reilein, D. Tcheng, D. Weber, B. Carragher, Leginon: A system for fully automated acquisition of 1000 electron micrographs a day. Ultramicroscopy 77, 153-161 (1999). doi:10.1016/S0304-3991(99)00043-1 Medline

54. N. R. Voss, C. K. Yoshioka, M. Radermacher, C. S. Potter, B. Carragher, DoG Picker and TiltPicker: Software tools to facilitate particle selection in single particle electron microscopy. J. Struct. Biol. 166, 205-213 (2009). doi:10.1016/i.jsb.2009.01.004 Medline

55. S. H. Scheres, RELION: Implementation of a Bayesian approach to cryo-EM structure determination. J. Struct. Biol. 180, 519-530 (2012). doi:10.1016/i.jsb.2012.09.006 Medline

56. E. F. Pettersen, T. D. Goddard, C. C. Huang, G. S. Couch, D. M. Greenblatt, E. C. Meng, T. E. Ferrin, UCSF Chimera-A visualization system for exploratory research and analysis. J. Comput. Chem. 25, 1605-1612 (2004). do::10.1002/jec.20084 Medline

\section{ACKNOWLEDGMENTS}

We thank Colin Russell and Alvin Han for helpful comments on the manuscript and Jelle Koopsen with the phylogenetic analyses. We thank Hannah Turner, Bill Anderson, and Charles Bowman for assistance with the electron microscopy studies. Funding: This study was supported by the Netherlands Organization for Scientific Research (NWO) Vici grant (to R.W.S.), by the Bill \& Melinda Gates Foundation through the Collaboration for AIDS Vaccine Discovery (CAVD), grants OPP1111923, OPP1132237, and INV-002022 (to R.W.S.), OPP1170236 (A.B.W.), by the Fondation Dormeur, Vaduz (to R.W.S. and to M.J.v.G.) and Health Holland PPS-allowance LSHM20040 (to M.J.v.G.) and by the Netherlands Organisation for Health Research and Development (ZONMW, to B.L.H). M.J.v.G. is a recipient of an AMC Fellowship, Amsterdam UMC and a COVID-19 grant of the Amsterdam Institute of Infection and Immunity, the Netherlands. R.W.S and M.J.v.G. are recipients of support from the University of Amsterdam Proof of Concept fund (contract no 200421) as managed by Innovation Exchange Amsterdam (IXA). The funders had no role in study design, data collection, data analysis, data interpretation or data reporting. Author contributions: P.J.M.B., T.G.C., K.v.d.S., G.V., B.H., A.B.W., G.J.d.B., R.W.S., and M.J.v.G. conceived and designed experiments; K.v.d.S., W.J.W., N.K., and G.d.B arranged medical ethical approval, recruitment of study participants and collection of study material. P.J.M.B., T.G.C., J.L.S., Y.A., S.B., J.L.T., N.M.A.O., G.K., A.E.H.B., M.M.v.H., D.G., J.A.B., E.E.S., K.D.V., J.v.S., M.J.v.B., T.P.L.B., K.S., R.D and I.B performed the experiments; P.J.M.B., T.G.C., M.C., and A.A., set up experimental assays. P.J.M.B., T.G.C., K.v.d.S., N.v.d.V., A.v.d.K., R.W.S and M.J.v.G. analyzed and interpreted data; P.J.M.B., T.G.C., K.v.d.S., G.J.d.B., R.W.S., and M.J.v.G. wrote the manuscript with input from all listed authors. Competing interests: Amsterdam UMC has filed a patent application concerning the SARS-CoV-2 mAbs described here. Data and materials availability: Reagents and materials presented in this study are available from the corresponding authors under an MTA with the Amsterdam UMC. Variable domain sequences of $\mathrm{HC}$ and $\mathrm{LCS}$ are available in table $\mathrm{Sl}$ and were uploaded on GenBank under accession numbers MT599820 - MT599987. The coordinates of the negative stain electron microscopy reconstructions were deposited in the Electron Microscopy Data Bank under accession numbers EMD-22061-22066. This work is licensed under a Creative Commons Attribution 4.0 International (CC BY 4.0) license, which permits unrestricted use, distribution, and reproduction in any medium, provided the original work is properly cited. To view a copy of this license, visit https:/creativecommons.org/licenses/by/4.0/. This license does not apply to figures/photos/artwork or other content included in the article that is credited to a third party; obtain authorization from the rights holder before using such material.

\section{SUPPLEMENTARY MATERIALS}

science.sciencemag.org/cgi/content/full/science.abc5902/DC1

Materials and Methods

Figs. S1 to S5

References (46-56)

Tables S1 and S2

MDAR Reproducibility Checklist

4 May 2020; accepted 10 June 2020

Published online 15 June 2020

10.1126/science.abc5902 
A

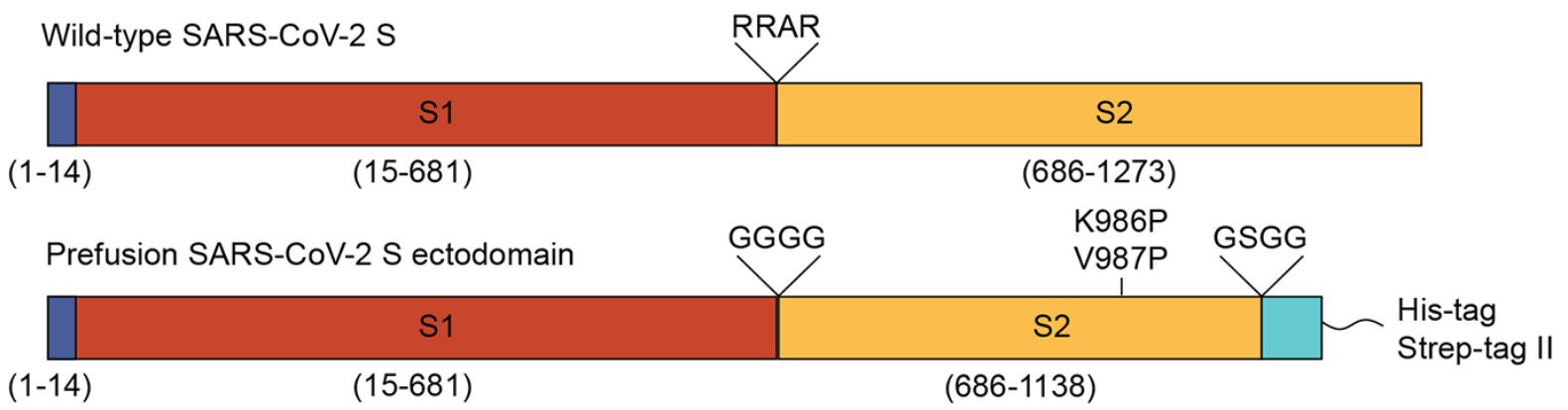

B

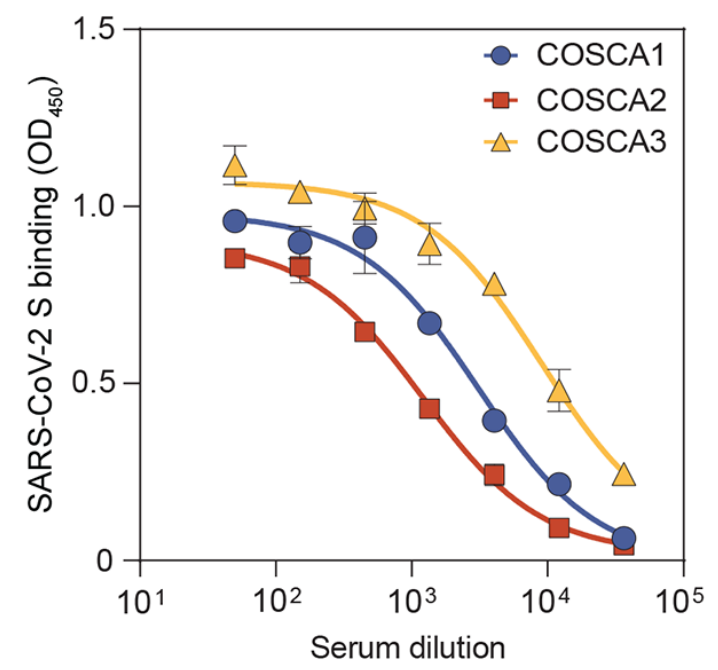

C

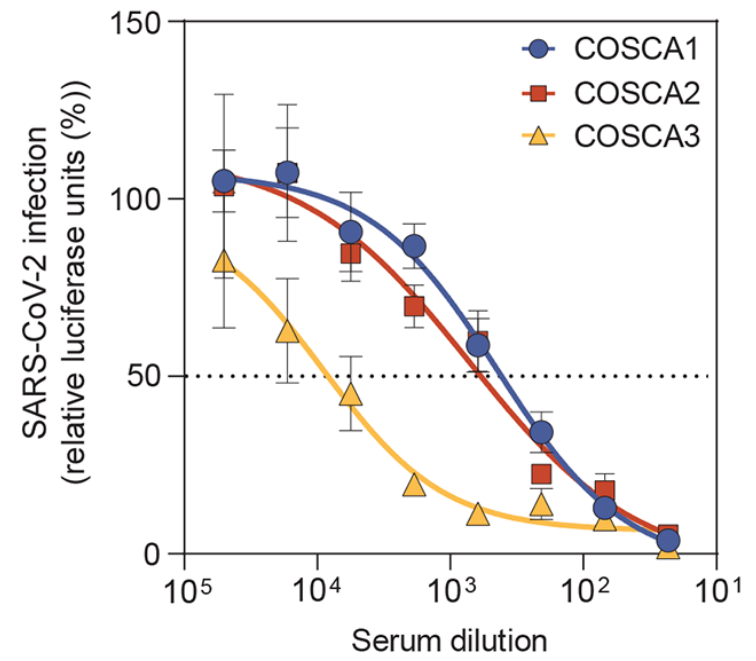

Fig. 1. Design of SARS-CoV-2 S protein and serology of COSCA1-3. (A) Schematic overview of the authentic SARSCoV-2 S protein with the signal peptide shown in blue and the S1 (red) and S2 (yellow) domain separated by a furincleavage site (RRAR; top). Schematic overview of the stabilized prefusion SARS-CoV-2 S ectodomain, where the furin cleavage site is replaced for a glycine linker (GGGG), two proline mutations are introduced (K986P and V987P) and a trimerization domain (cyan), preceded by a linker (GSGG) is attached (bottom). (B) Binding of COSCA1-3 sera to prefusion SARS-CoV-2 S protein as determined by ELISA. The mean values and standard deviations of two technical replicates are shown. (C) Neutralization of SARS-CoV-2 pseudovirus by heat-inactivated COSCA1-3 sera. The mean with SEM of at least three technical replicates are shown. The dotted line indicates $50 \%$ neutralization. 
A
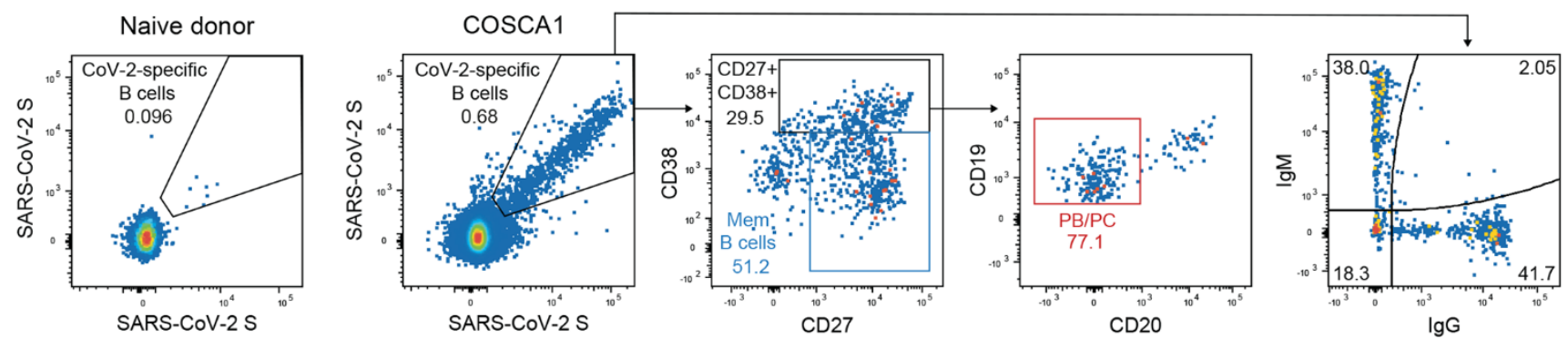

B

C
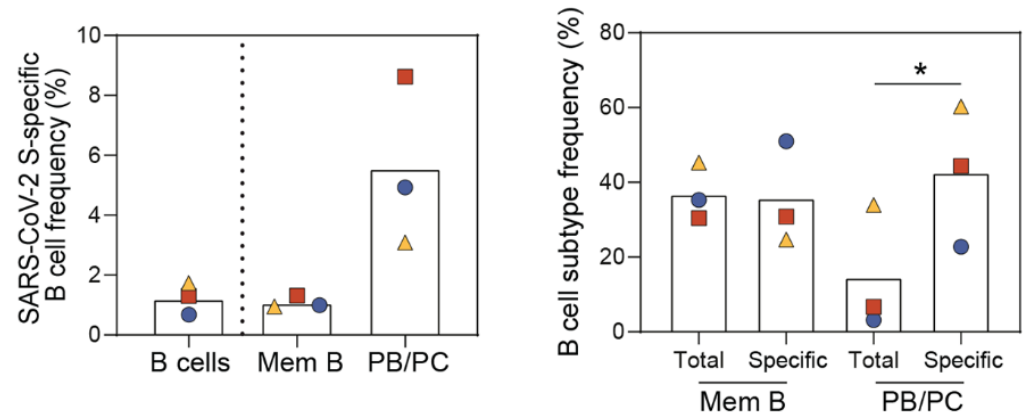

D

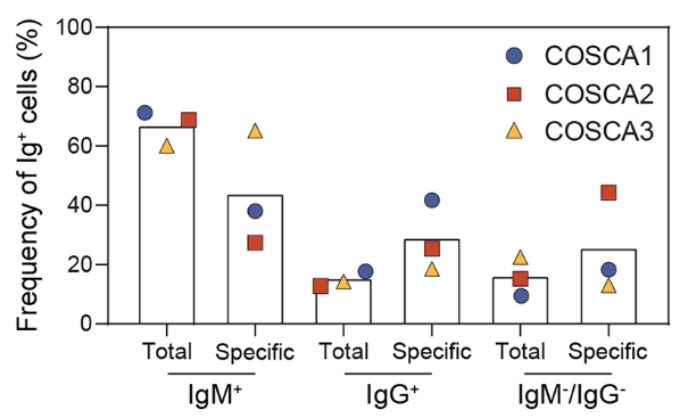

Fig. 2. Characterization of SARS-CoV-2 S-specific B cells derived from COSCA1-3. (A) Representative gates of SARS-CoV-2 S-specific B cells, shown for a naive donor (left panel) or COSCA1 (middle left panel). Each dot represents a B cell. The gating strategy to identify $B$ cells is shown in fig. S2. From the total pool of SARS-CoV-2 Sspecific B cells, CD27+CD38 (memory B cells (Mem B cells; blue gate)) and CD27 ${ }^{+} \mathrm{CD} 38^{+} \mathrm{B}$ cells were identified (middle panel). From the latter gate, plasmablasts/plasma cells (PB/PC; CD20; red gate) could be identified (middle right panel). SARS-CoV-2 S-specific B cells were also analyzed on their IgG or IgM isotype (right panel). (B) Frequency of SARS-CoV-2 S-specific B cells in total B cells, Mem B cells and PB/PC. Symbols represent individual patients as shown in panel 2D. (C) Comparison of the frequency of Mem B cells (CD27+CD38) and PB/PC cells $\left(\mathrm{CD} 27^{+} \mathrm{CD} 38^{+} \mathrm{CD} 2 \mathrm{O}^{-}\right)$between the specific (SARS-CoV2 $\mathrm{S}^{++}$) and non-specific B cells (gating strategy shown in fig. S2). Symbols represent individual patients as shown in panel 2D. Statistical differences between two groups were determined using paired $t$ test $(*, p=0.034)$. (D) Comparison of the frequency of $\operatorname{lgM}^{+}, \lg \mathrm{G}^{+}, \lg M^{-} \lg \mathrm{G}^{-} \mathrm{B}$ cells in specific and non-specific compartments. Bars represent means, symbols represent individual patients. 
A

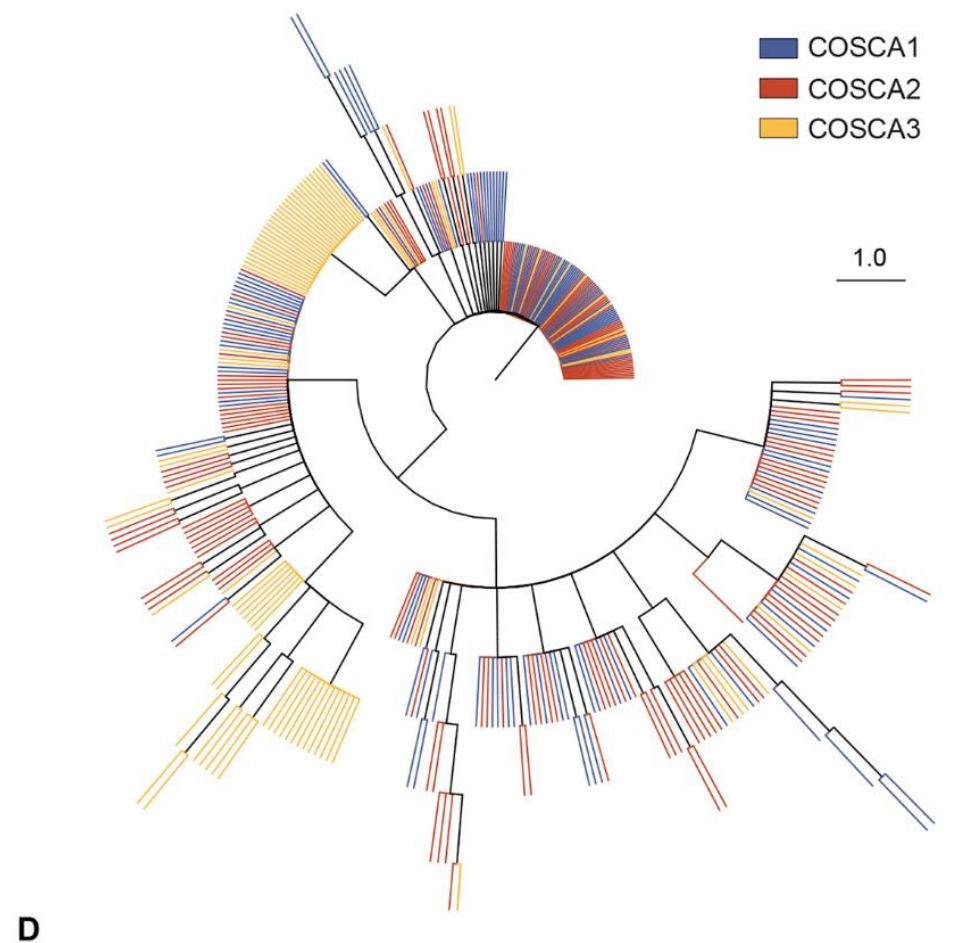

B

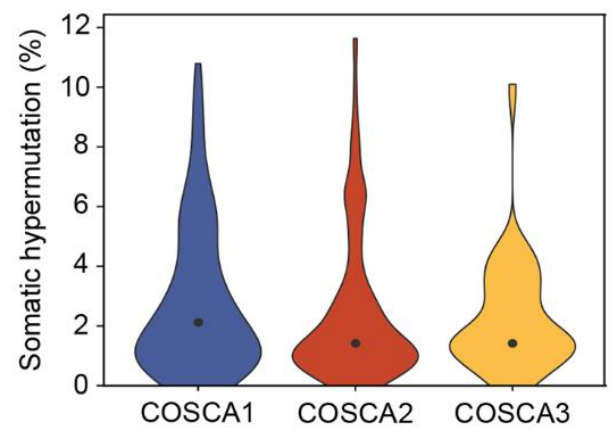

C

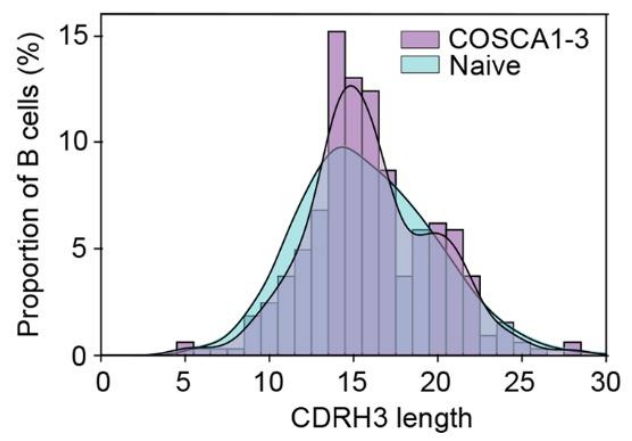

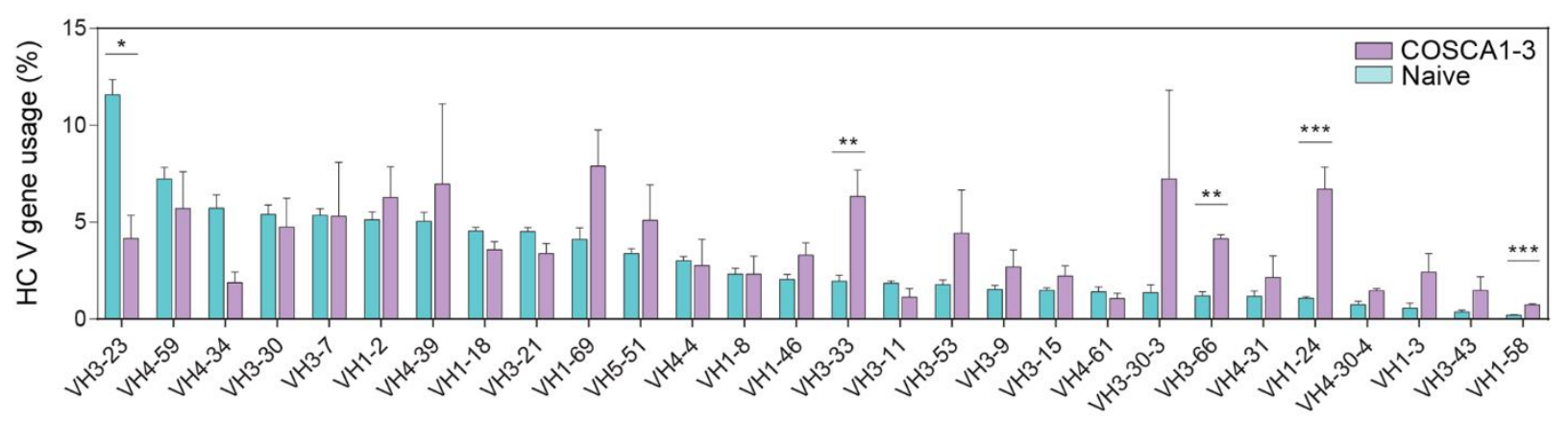

Heavy chain $V$ gene

Fig. 3. Genotypic characterization of SARS-CoV-2 S-specific B cell receptors. (A) Maximum-likelihood phylogenetic tree of 409 isolated paired B cell receptor heavy chains. Each color represents sequences isolated from different patients (COSCA1-3). (B) Violin plot showing somatic hypermutation (SHM) levels (\%; nucleotides) per patient. The dot represents the median SHM percentage. (C) The distribution of CDRH3 lengths in B cells from COSCA1-3 (purple, $n=323$ ) versus a representative naive population from three donors (cyan, $n=9.791 .115)(37)$. (D) Bar graphs showing the mean ( \pm SEM) VH gene usage $(\%)$ in COSCA1-3 (purple, $n=323$ ) versus a representative naive population (cyan, $\mathrm{n}=363.506 .788$ ). The error bars represent the variation between different patients (COSCA1-3) or naive donors (37). Statistical differences between two groups were determined using unpaired $t$ tests (Holm-Sidak correction for multiple comparisons, adjusted $p$ values: ${ }^{*}, p<0.05 ;{ }^{* *}, p<0.01 ;{ }^{* *}, p<0.001$ ). 
A

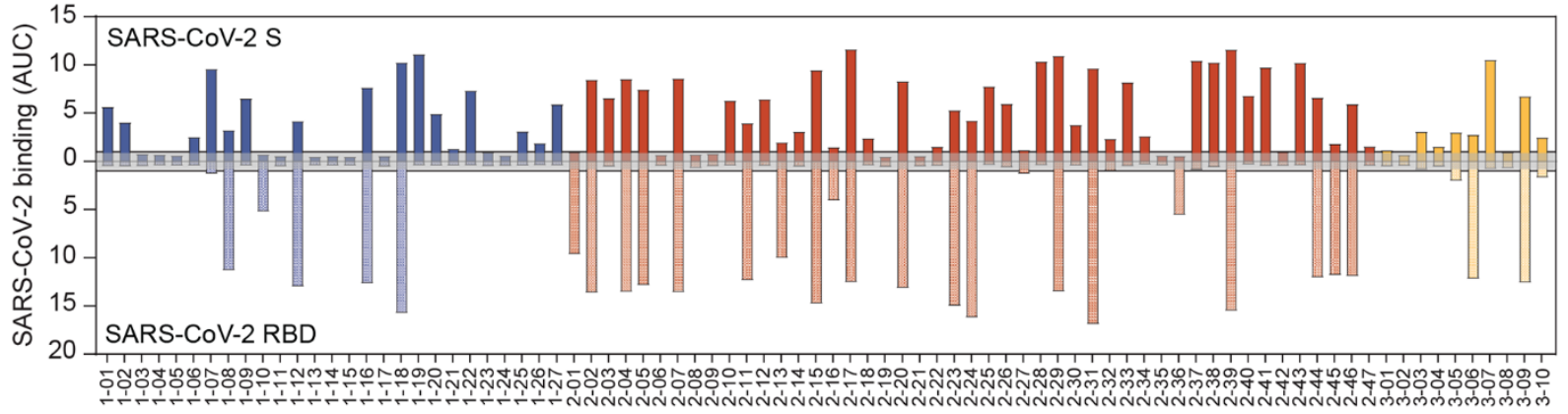

B

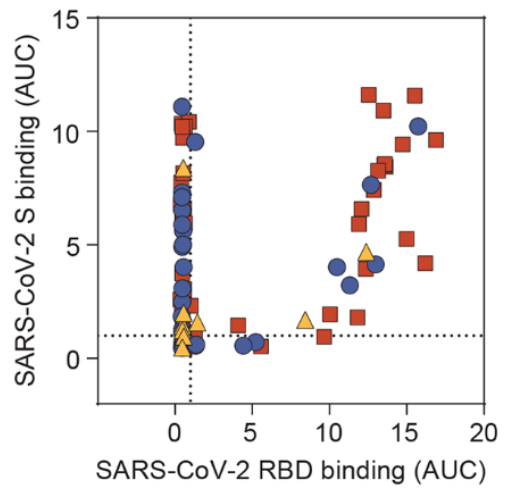

C

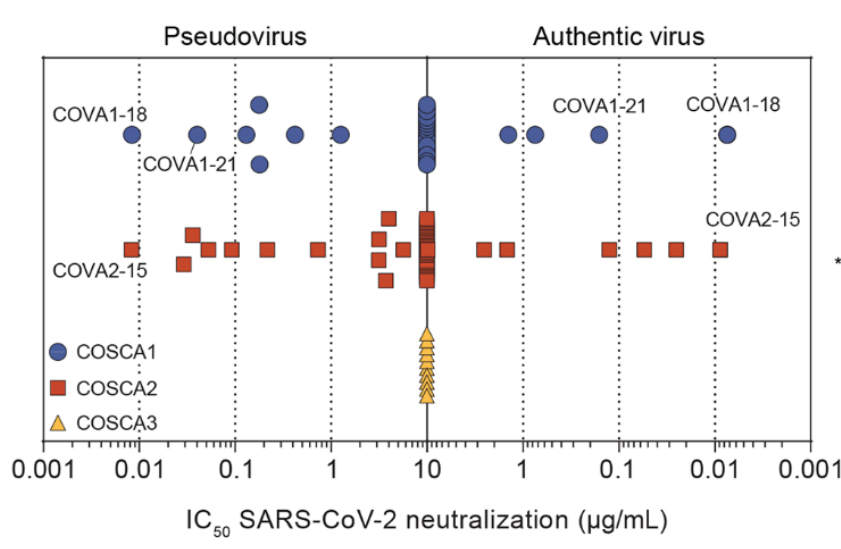

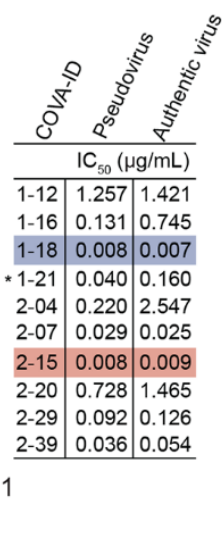

Fig. 4. Phenotypic characterization of SARS-CoV-2 S-specific mAbs. (A) Bar graph depicting the binding of $m A b s$ from COSCA1 (blue), COSCA2 (red) and COSCA3 (yellow) to SARS-CoV-2 S protein (dark shading) and SARS-CoV2 RBD (light shading) as determined by ELISA. Each bar indicates the representative area under the curve (AUC) of the $\mathrm{mAb}$ indicated below from two experiments. The grey area represents the cutoff for binding ( $A \cup C=1)$. The maximum concentration of $\mathrm{mAb}$ tested was $10 \mu \mathrm{g} / \mathrm{mL}$. (B) Scatter plot depicting the binding of mAbs from COSCA13 (see panel 4C for color coding) to SARS-CoV-2 S protein and SARS-CoV-2 RBD as determined by ELISA. Each dot indicates the representative AUC of a mAb from two experiments. (C) Midpoint neutralization concentrations (IC $\left.\mathrm{C}_{50}\right)$ of SARS-CoV-2 pseudovirus (left) or authentic SARS-CoV-2 virus (right). Each symbol represents the $I C_{50}$ of a single $\mathrm{mAb}$. For comparability, the highest concentration was set to $10 \mu \mathrm{g} / \mathrm{mL}$ although the actual start concentration for the authentic virus neutralization assay was $20 \mu \mathrm{g} / \mathrm{mL}$. The $I_{50}$ for pseudotyped and authentic SARS-CoV-2 virus of a selection of potently neutralizing RBD and non-RBD-specific mAbs (with asterisk) are shown in the adjacent table. Colored shading indicates the most potent mAbs from COSCA1-2. 


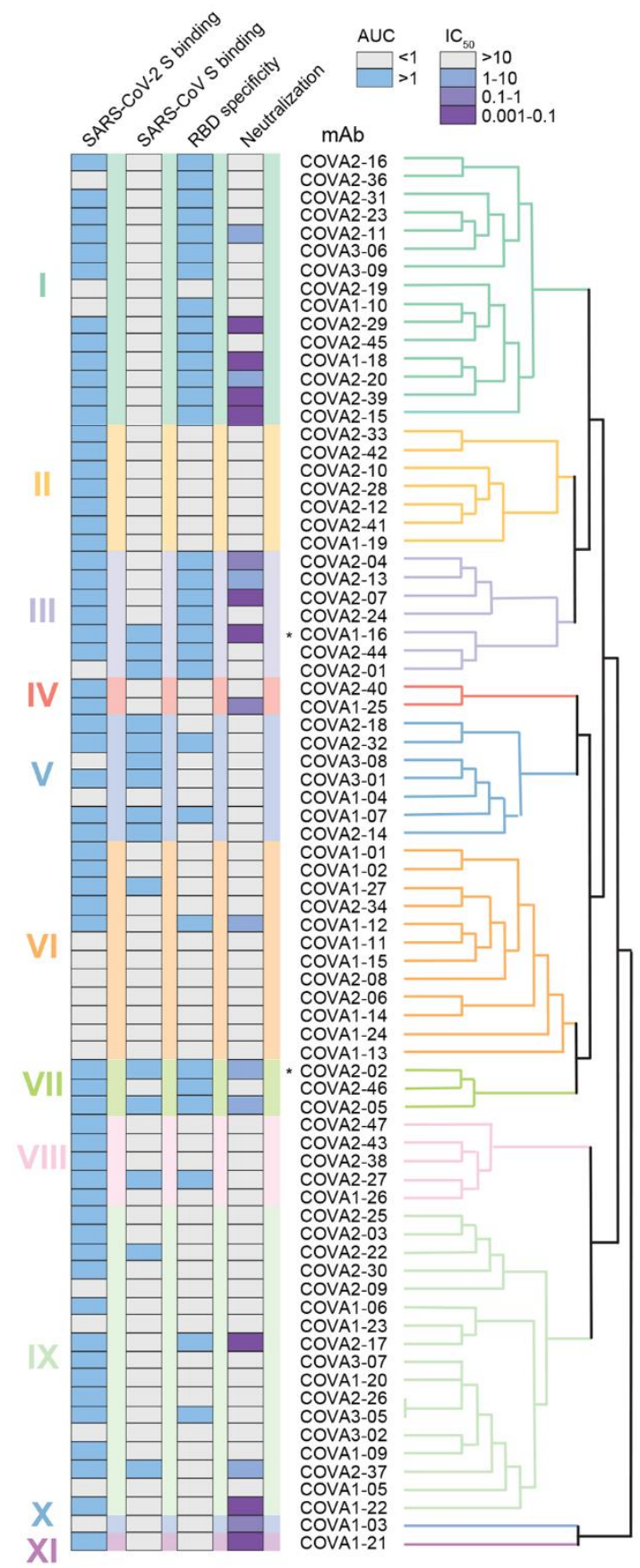

B

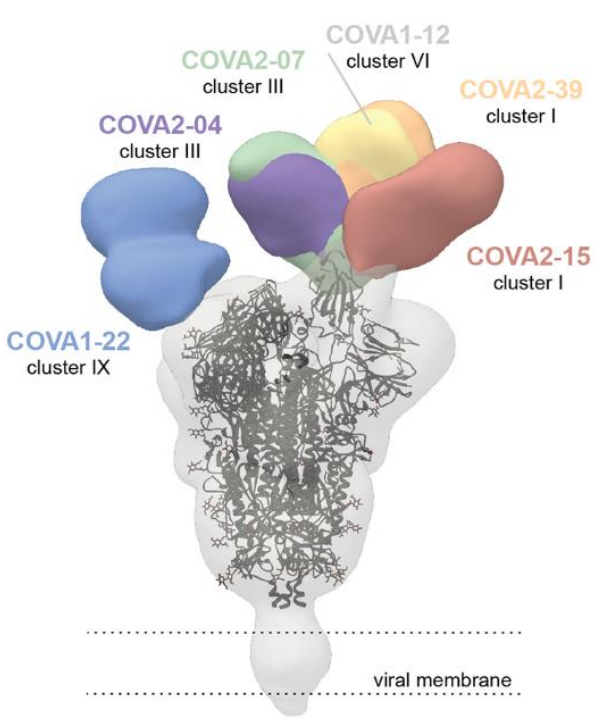

C

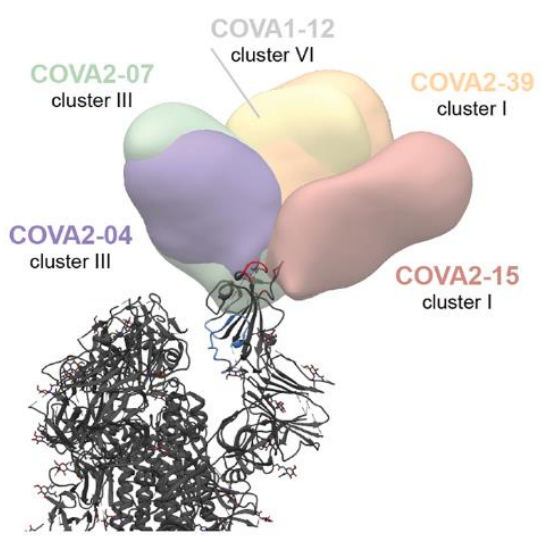

D

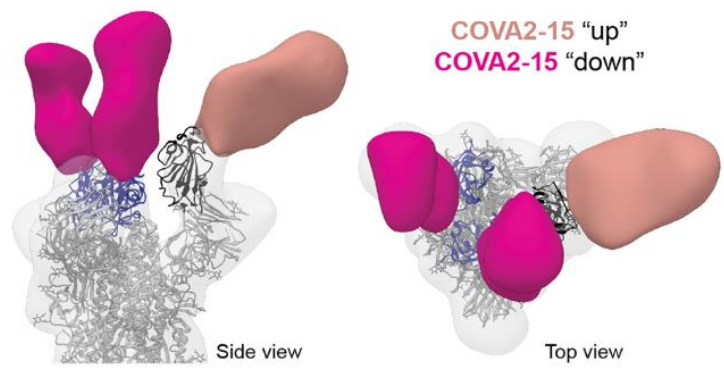

Fig. 5. Antigenic clustering of SARS-CoV-2 specific mAbs. (A) Dendrogram showing hierarchical clustering of the SPR-based cross-competition heat map (table S2). Clusters are numbers I-XI and depicted with color shading. ELISA binding to SARS-CoV-2 S, SARS-CoV S and SARS-CoV-2 RBD as presented by AUC and neutralization $\mathrm{IC}_{50}(\mu \mathrm{g} / \mathrm{mL})$ of SARS-CoV-2 are shown in the columns on the left. ELISA AUCs are shown in grey $(A \cup C<1)$, or blue $(A \cup C>1)$ and neutralization $\mathrm{IC}_{50}$ is shown in grey $(>10 \mu \mathrm{g} / \mathrm{mL})$, blue $(1-10 \mu \mathrm{g} / \mathrm{mL})$, violet $\left(0.1^{-}\right.$ $1 \mu \mathrm{g} / \mathrm{mL})$ or purple $(0.001-0.1 \mu \mathrm{g} / \mathrm{mL})$. Asterisks indicate antibodies that cross-neutralize SARS-CoV pseudovirus. (B) Composite figure demonstrating binding of NTD-mAb COVA1-22 (blue) and RBD mAbs COVA2-07 (green), COVA2-39 (orange), COVA1-12 (yellow), COVA2-15 (salmon) and COVA2-04 (purple) to SARS-CoV-2 spike (grey). The spike model (PDB 6VYB) is fit into the density. (C) Zoom in of SARS-CoV-2 spike comparing epitopes of RBD mAbs to the ACE2 binding site (red) and the epitope of mAb CR3022 (blue). (D) Side (left) and top (right) views of 3D reconstruction of COVA2-15 bound to SARS-CoV-2 S protein. COVA2-15 binds to both the down (magenta) and up (salmon) conformations of the RBD. The RBDs are colored blue in the down conformation and black in the up conformation. The angle of approach for COVA2-15 enables this broader recognition of the RBD while also partially overlapping with the ACE-2 binding site and therefore blocking receptor engagement. 
Table 1. Patient characteristics, symptoms of COVID-19, treatment modalities and sampling time point of three SARS-CoV-2 infected patients. The numbers indicate the day of symptom onset-relief, treatment period and sampling time point in days following symptom onset. ICU: Intensive Care Unit. NSAIDs: Non-Steroidal Anti-Inflammatory Drugs.

\begin{tabular}{|c|c|c|c|}
\hline Patient characteristics & COSCA1 & COSCA2 & COSCA3 \\
\hline Age (years) & 47 & 44 & 69 \\
\hline Gender & Male & Female & Male \\
\hline Co-morbidities & None & None & None \\
\hline \multicolumn{4}{|l|}{ Symptoms } \\
\hline Fever $\left(>38^{\circ} \mathrm{C}\right)$ & $4-10$ & $1-4$ & $6-18$ \\
\hline Coughing & $2-35$ & $3-17$ & $1-20$ \\
\hline Sputum production & $2-35$ & No & $1-20$ \\
\hline Dyspnoea & $4-24$ & No & No \\
\hline Sore throat & $1-5$ & $5-17$ & No \\
\hline Rhinorrhoea & $2-34$ & $5-17$ & No \\
\hline Anosmia & No & $5-17$ & No \\
\hline Myalgia & No & $1-4$ & $6-18$ \\
\hline Headache & No & No & $1-18$ \\
\hline Other & No & No & Delirium \\
\hline \multicolumn{4}{|l|}{ Treatment modalities } \\
\hline Hospital admission & No & No & $8-24$ \\
\hline ICU admission & No & No & $11-18$ \\
\hline Oxygen therapy & No & No & $8-24$ \\
\hline Intubation & No & No & $11-16$ \\
\hline Dialysis & No & No & No \\
\hline \multicolumn{4}{|l|}{ Drug therapy } \\
\hline Antiviral & No & No & No \\
\hline Antibiotic & No & No & $\begin{array}{l}\text { Cefotaxime 8-12 } \\
\text { Ciprofloxacin 8-11 }\end{array}$ \\
\hline Immunomodulatory & No & No & No \\
\hline NSAIDs & No & No & No \\
\hline Sampling time point & 27 & 28 & 23 \\
\hline
\end{tabular}

